Article

\title{
Chemical Constituents from Scindapsus officinalis (Roxb.) Schott. and Their Anti-Inflammatory Activities
}

\author{
Hongjing Dong ${ }^{1}$, Yanling Geng ${ }^{1}$, Xueyong Wang ${ }^{2}$, Xiangyun Song ${ }^{1}$, Xiao Wang ${ }^{1}$ and \\ Jinqian $\mathrm{Yu}^{1, *}$ \\ 1 Shandong Key Laboratory of TCM Quality Control Technology, Shandong Analysis and Test Center, \\ Qilu University of Technology (Shandong Academy of Sciences), Jinan 250014, China; \\ donghongjing_2006@163.com (H.D.); gengyanling@163.com (Y.G.); sxyun198806@163.com (X.S.); \\ wangx@sdas.org (X.W.) \\ 2 College of Chinese Mareria Medica, Beijing University of Chinese Medicine, Beijing 100102, China; \\ xueyongwang@bucm.edu.cn \\ * Correspondence: yujinqian87528@126.com; Tel.: +86-0531-8260-5319
}

Received: 4 September 2018; Accepted: 1 October 2018; Published: 9 October 2018

\begin{abstract}
One new monoterpene glycoside (1), one new phenyl glycoside (2), one new caffeoyl derivative (3), were isolated from Scindapsus officinalis (Roxb.) Schott., along with four known compounds (4-7). Structures of the isolated compounds were elucidated by extensive analysis of spectroscopic data, especially 2D NMR data and comparison with literatures. All isolates were evaluated for anti-inflammatory activity against nitric oxide (NO) production in vitro. Compounds 3 and 7 exhibited moderate inhibitory effects on $\mathrm{NO}$ production with $\mathrm{IC}_{50}$ values of $12.2 \pm 0.8$ and 18.9 $\pm 0.3 \mu \mathrm{M}$, respectively.
\end{abstract}

Keywords: Scindapsus officinalis; monoterpene glycoside; phenyl glycoside; caffeoyl derivative; anti-inflammatory activity

\section{Introduction}

The family of Araceae plants, comprising 115 genera and more than 2100 species, is distributed all over the world. However, $90 \%$ of the species is predominantly found in tropical America, India, Malaya, and South China [1]. Araceae plants are generally recognized as a rich source of biologically active and structurally unique compounds, such as alkaloids, phenols, saponins, sterols and so on [2-6]. The chemical diversities reported for Araceae plants are fascinating from a pharmacological viewpoint. Scindapsus officinalis (Roxb.) Schott. is a large, epiphytic, and perennial liana in the family Araceae, which usually climbs up to trees and rocks using aerial roots and is mainly distributed in the south-central regions of China and the tropical parts of India. The whole plant of S. officinalis has been used in Guizhou, Yunnan and Guangxi Provinces in China as ethnomedicine to treat bone fractures, arthralgia, bronchitis, and pertussis [7]. According to its usage in ethnomedicine, the whole plant of S. officinalis is confirmed to show anti-inflammatory activity. However, a literature search indicates that limited studies have been conducted on the anti-inflammatory chemical constituents of the whole plant up to now, including only several chromone derivatives and alkaloids obtained by our group [8,9]. As part of our ongoing commitment to search for novel, structurally intriguing, and anti-inflammatory natural products from $S$. officinalis, one new monoterpene glycoside (1), one new phenyl glycoside (2), one new caffeoyl derivative (3), and four known compounds (4-7) (Figure 1), were isolated. Herein, the isolation and structural elucidation toward the new compounds, as well as 
the inhibitory effect of all the isolated compounds on lipoplysaccharide (LPS)-induced NO production in RAW 264.7 cells, are described.

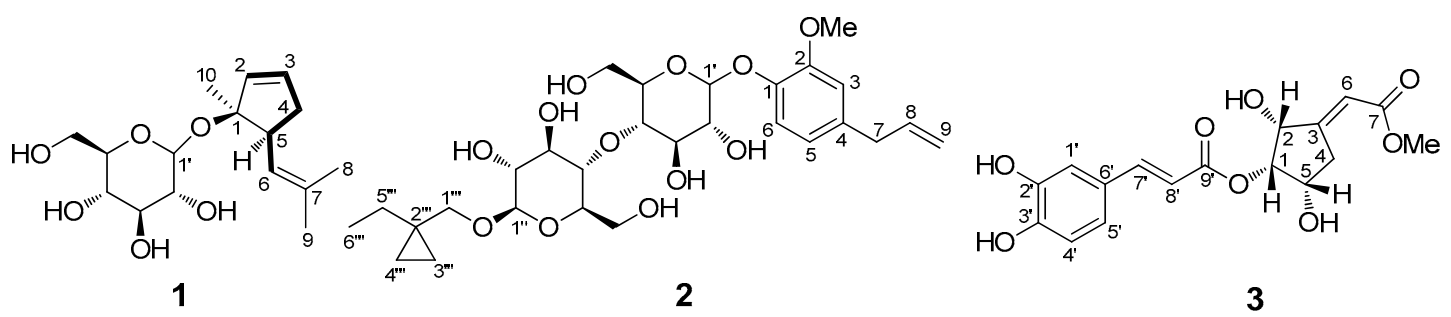<smiles>CCCCCCOC1O[C@H](CO)[C@@H](O)[C@H](O)[C@H]1O</smiles>

Figure 1. Structures of compounds $1-7$ and ${ }^{1} \mathrm{H}-{ }^{1} \mathrm{H}$ COSY (bold) of $\mathbf{1}$.

\section{Results}

The condensed $95 \%$ ethanol (EtOH) extract of S. officinalis was suspended in $20 \%$ ethanol solution and successively subjected to multi-solvent partition with petroleum ether, ethyl acetate (EtOAc), and $n$-butanol $(n-\mathrm{BuOH})$. The EtOAc fraction was subjected to diverse column chromatography to furnish seven compounds, including one new monoterpene glycoside (1), one new phenyl glycoside (2), one new caffeoyl derivative (3), and four known compounds (4-7). By comparison with previous NMR data in the literature, the known compounds were identified as caffeic acid (4) [10], 2-phenylethyl $\beta$-D-Glucopyranoside (5) [11], hexyl-O- $\beta$-D-Glucopyranoside (6) [12], and methyl gallate (7) [13], which were isolated from $S$. officinalis for the first time.

Compound 1 was obtained as a brown gum. Its molecular formula was established as $\mathrm{C}_{16} \mathrm{H}_{26} \mathrm{O}_{6}$ from its ${ }^{13} \mathrm{C}-\mathrm{NMR}$ data and a sodium adduct molecular ion peak at $m / z 337.1657[\mathrm{M}+\mathrm{Na}]^{+}$in the HRESIMS (positive ion mode) spectrum (calcd for $\mathrm{C}_{16} \mathrm{H}_{26} \mathrm{NaO}_{6}, 337.1622$ ), representing four degrees of unsaturation. The ${ }^{1} \mathrm{H}-\mathrm{NMR}$ spectrum of $\mathbf{1}$ (Table 1 ) indicated the presence of three olefinic protons at $\delta_{\mathrm{H}} 5.98(1 \mathrm{H}, \mathrm{dd}, J=11.2,17.6 \mathrm{~Hz}, \mathrm{H}-2)$ and $5.09(2 \mathrm{H}$, overlapped, $\mathrm{H}-3,6)$, and three methyls at $\delta_{\mathrm{H}}$ $1.61(3 \mathrm{H}, \mathrm{s}, \mathrm{Me}-8), 1.54(3 \mathrm{H}, \mathrm{s}, \mathrm{Me}-9)$ and $1.22(3 \mathrm{H}, \mathrm{s}, \mathrm{Me}-10)$. In addition, one obvious anomeric proton at $\delta_{\mathrm{H}} 4.13\left(1 \mathrm{H}, \mathrm{d}, J=8.0 \mathrm{~Hz}, \mathrm{H}-1^{\prime}\right)$ which correlated with carbon signal at $\delta_{\mathrm{C}} 105.1\left(\mathrm{C}-1^{\prime}\right)$ observed in the HSQC spectrum, indicated one pyranose moiety. The relatively large coupling constant suggested that the pyranose moiety possessed a $\beta$-glycosidic bond. The ${ }^{13} \mathrm{C}-\mathrm{NMR}$ data of $\mathbf{1}$ exhibited a total of sixteen carbon signals (Table 1) assignable via HSQC spectrum to three methyls, two methylenes (including one oxygenated carbon at $\delta_{\mathrm{C}} 61.7\left(\mathrm{C}-6^{\prime}\right)$ ), nine methines [including three olefinic carbons at $\delta_{\mathrm{C}} 144.1(\mathrm{C}-2), 114.1(\mathrm{C}-3), 125.3(\mathrm{C}-6)$, five oxygenated methines, and one anomeric carbon at $\delta_{\mathrm{C}}$ $\left.98.2\left(\mathrm{C}-1^{\prime}\right)\right]$, and two quaternary carbons (including one olefinic carbon at $\delta_{\mathrm{C}} 130.8(\mathrm{C}-7)$ and one mono-oxygen-connected carbon at $\delta_{\mathrm{C}} 79.4(\mathrm{C}-1)$ ), with ten assigned to the aglycon part, and six to a pyranose moiety. The sugar moiety which was consistent with D-glucose underwent GC analysis of the derivatives of its hydrolysis product and was compared with a referenced D-glucose.

The 2D NMR spectroscopic data of 1 was analyzed in detail to determine the 2D structure of the aglycone part. Starting from the typical olefinic proton of $\mathrm{H}-2$, the ${ }^{1} \mathrm{H}^{1} \mathrm{H}-\mathrm{COSY}$ cross-peaks of $\mathrm{H}-2 / \mathrm{H}-3 / \mathrm{H}-4\left(\delta_{\mathrm{H}} 1.96\right) / \mathrm{H}-5$ (Figure 1$)$, coupled with the significant HMBC correlations of H-2/C-1 and $\mathrm{C}-5 ; \mathrm{H}-3 / \mathrm{C}-1, \mathrm{C}-2$, and $\mathrm{C}-5 ; \mathrm{H}-4 / \mathrm{C}-1$ and $\mathrm{C}-5 ; \mathrm{H}-5 / \mathrm{C}-1, \mathrm{C}-2$ and $\mathrm{C}-4$ suggested the presence of a cyclopentene moiety ( $\mathrm{C}-1$ to $\mathrm{C}-5)$ in 1 . The remaining signals for the aglycone part were speculated as a 2-methylprop-1-ene moiety (C-6 to C-9) on the basis of NMR data and the correlations from H-6 to C-7, Me-8 and Me-9; from Me-8 to C-6, C-7 and Me-9; from Me-9 to C-6, C-7 and Me-8 in the HMBC spectrum. Additionally, ${ }^{1} \mathrm{H}^{1} \mathrm{H}-\mathrm{COSY}$ cross-peak of $\mathrm{H}-5 / \mathrm{H}-6$ and $\mathrm{HMBC}$ correlations between: $\mathrm{H}-5$ to C-6 and also H-6 to C-4 (Figures 1 and 2), demonstrated the two moieties were fused through 
C-5/C-6 linkage. The position of Me-10 was assigned at C- 1 and was deduced by HMBC correlations from Me-10 to C-1, C-2 and C-5 (Figure 2). Thus, the planar structure of the aglycone part for 1 was determined as in Figure 1. The location the sugar unit was thus unequivocally established to be at $\mathrm{C}-1$ by the key HMBC correlation data from $\mathrm{H}-1^{\prime}$ glc to $\mathrm{C}-1\left(\delta_{\mathrm{C}} 79.4\right)$ (Figure 2).

The relative configurations of $\mathbf{1}$ at $\mathrm{C}-1$ and $\mathrm{C}-5$ positions were unambiguously assigned by interpretation of the observed NOESY correlations (Figure 2). The relative $5 \alpha$ and Me-10 $\alpha$ configurations were determined by the NOESY correlations from $\mathrm{H}-5$ to $\mathrm{H}-4, \mathrm{H}-6, \mathrm{Me}-10$ and $\mathrm{H}-1^{\prime}$; from Me-10 to H-2, H-3, H-4, H-5 and H-1'. Finally, compound 1 was identified as (rel)-(1R, 5R)-1-methyl-5-(2-methylprop-1-en-1-yl)cyclopent-2-en-1-O- $\beta$-d-glucopyranosideby using a molecular modeling program called Chem 3D Ultra 14.0, which used MM2 force field calculations for energy minimization to provide a detailed computer-modeled 3D structure.

Table $1 .{ }^{1} \mathrm{H}$ and ${ }^{13} \mathrm{C}-\mathrm{NMR}$ spectroscopic data of $1-3$ (in DMSO- $d_{6}$, TMS) $(\delta$ in ppm, $J$ in $\mathrm{Hz}$ ).

\begin{tabular}{|c|c|c|c|c|c|c|}
\hline Positions & $1^{a}$ & & $2^{b}$ & & $3^{b}$ & \\
\hline 1 & & 79.4 & & 144.86 & $5.10 \mathrm{dd}(4.8,6.6)$ & 70.2 \\
\hline 2 & $5.98 \mathrm{dd}(11.2,17.6)$ & 144.1 & & 144.87 & $3.78 \mathrm{dd}(4.2,6.6)$ & 68.0 \\
\hline 3 & 5.09 overlapped & 114.1 & $6.80 \mathrm{~d}(1.8)$ & 112.9 & & 127.4 \\
\hline $4 a$ & $1.96 \mathrm{~m}$ & 22.6 & & 133.4 & $2.65-2.69 \mathrm{~m}$ & 27.9 \\
\hline $4 b$ & & & & & $2.21-2.25 \mathrm{~m}$ & \\
\hline 5 & $1.50 \mathrm{~m}$ & 40.2 & $6.67 \mathrm{dd}(1.8,8.4)$ & 120.8 & $4.28 \mathrm{~m}$ & 65.8 \\
\hline 6 & 5.09 overlapped & 125.3 & $7.00 \mathrm{~d}(8.4)$ & 115.53 & 6.72 brs & 140.1 \\
\hline 7 & & 130.8 & $3.30 \mathrm{~d}(6.6)$ & 39.1 & & 166.7 \\
\hline 8 & $1.61 \mathrm{~s}$ & 25.9 & $5.94 \mathrm{~m}$ & 137.9 & & \\
\hline 9 & $1.54 \mathrm{~s}$ & 18.0 & $5.03-5.08 \mathrm{~m}$ & 115.49 & & \\
\hline 10 & $1.22 \mathrm{~s}$ & 24.0 & & & & \\
\hline $1^{\prime}$ & $4.13 \mathrm{~d}(8.0)$ & 98.2 & $4.84 \mathrm{~d}(7.2)$ & 100.2 & & 125.9 \\
\hline $2^{\prime}$ & $2.90 \mathrm{~m}$ & 74.0 & $3.23-3.28 \mathrm{~m}$ & 73.1 & $7.05 \mathrm{~d}(2.0)$ & 115.3 \\
\hline $3^{\prime}$ & $3.09 \mathrm{t}(8.4)$ & 77.5 & $3.23-3.28 \mathrm{~m}$ & 76.98 & & 146.0 \\
\hline $4^{\prime}$ & $3.02 \mathrm{t}(9.2)$ & 70.7 & $3.23-3.28 \mathrm{~m}$ & 76.78 & & 148.9 \\
\hline $5^{\prime}$ & $2.95 \mathrm{~m}$ & 77.1 & $3.13-3.17 \mathrm{~m}$ & 69.7 & $6.76 \mathrm{~d}(8.4)$ & 116.2 \\
\hline $6^{\prime} \mathrm{a}$ & $3.58 \mathrm{~d}(11.2)$ & 61.7 & $3.65-3.67 \mathrm{~m}$ & 60.8 & $7.01 \mathrm{dd}(2.0,8.4)$ & 121.9 \\
\hline $6^{\prime} \mathrm{b}$ & $3.38 \mathrm{~m}$ & & $3.42-3.45 \mathrm{~m}$ & & & \\
\hline $7^{\prime}$ & & & & & $7.48 \mathrm{~d}(15.6)$ & 145.9 \\
\hline $8^{\prime}$ & & & & & $6.25 \mathrm{~d}(15.6)$ & 114.4 \\
\hline $9^{\prime}$ & & & & & & 166.5 \\
\hline $1^{\prime \prime}$ & & & $4.09 \mathrm{~d}(7.8)$ & 102.8 & & \\
\hline $2^{\prime \prime}$ & & & $2.93 \mathrm{td}(8.4,4.2)$ & 73.4 & & \\
\hline $3^{\prime \prime}$ & & & $3.05-3.08 \mathrm{~m}$ & 76.85 & & \\
\hline $4^{\prime \prime}$ & & & $3.10-3.13 \mathrm{~m}$ & 76.81 & & \\
\hline $5^{\prime \prime}$ & & & $3.01-3.05 \mathrm{~m}$ & 70.1 & & \\
\hline $6^{\prime \prime} \mathrm{a}$ & & & $3.65-3.67 \mathrm{~m}$ & 61.1 & & \\
\hline $6^{\prime \prime} \mathrm{b}$ & & & $3.42-3.45 \mathrm{~m}$ & & & \\
\hline $1^{\prime \prime \prime} \mathrm{a}$ & & & $3.74 \mathrm{~d}(13.2)$ & 68.5 & & \\
\hline $1^{\prime \prime \prime} \mathrm{b}$ & & & $3.40 \mathrm{~d}(13.2)$ & & & \\
\hline $2^{\prime \prime \prime}$ & & & & 31.2 & & \\
\hline $3^{\prime \prime \prime}$ & & & $1.23-1.32 \mathrm{ov}$ & 25.2 & & \\
\hline $4^{\prime \prime \prime} \mathrm{a}$ & & & $1.49-1.53 \mathrm{~m}$ & 29.2 & & \\
\hline $4^{\prime \prime \prime} \mathrm{b}$ & & & $1.23-1.32 \mathrm{ov}$ & & & \\
\hline $5^{\prime \prime \prime}$ & & & $1.23-1.32 \mathrm{ov}$ & 21.9 & & \\
\hline $6^{\prime \prime \prime}$ & & & $0.87 \mathrm{t}(7.2)$ & 13.9 & & \\
\hline $\mathrm{OMe}$ & & & $3.74 \mathrm{~s}(\mathrm{OMe}-2)$ & 55.6 & $3.69 \mathrm{~s}$ & 52.3 \\
\hline
\end{tabular}

${ }^{a}$ The NMR data were recorded in DMSO- $d_{6}$ at $400 \mathrm{MHz}$ for $\delta_{\mathrm{H}}$ and at $100 \mathrm{MHz}$ for $\delta_{\mathrm{C}} .{ }^{b}$ The NMR data were recorded in DMSO- $d_{6}$ at $600 \mathrm{MHz}$ for $\delta_{\mathrm{H}}$ and at $150 \mathrm{MHz}$ for $\delta_{\mathrm{C}}$.

Compound 2 was obtained as light-yellow amorphous powder. Its molecular formula was established as $\mathrm{C}_{28} \mathrm{H}_{42} \mathrm{O}_{12}$ from its ${ }^{13} \mathrm{C}$-NMR data and the protonated ion peak at $\mathrm{m} / z 571.2798[\mathrm{M}+\mathrm{H}]^{+}$ in the HRESIMS (positive ion mode) spectrum (calcd for $\mathrm{C}_{28} \mathrm{H}_{43} \mathrm{O}_{12}, 571.2749$ ), representing eight 
degrees of unsaturation. The ${ }^{1} \mathrm{H}-\mathrm{NMR}$ spectrum of 2 (Table 1) exhibited signals classified as one typical ABX coupling system of a 1,2,4-trisubstituted benzene at $\delta_{\mathrm{H}} 6.80(1 \mathrm{H}, \mathrm{d}, J=1.8 \mathrm{~Hz}, \mathrm{H}-3)$, $6.67(1 \mathrm{H}, \mathrm{dd}, J=1.8,8.4 \mathrm{~Hz}, \mathrm{H}-5)$, and $7.00(1 \mathrm{H}, \mathrm{d}, J=8.4 \mathrm{~Hz}, \mathrm{H}-6)$, one terminal double bond at $\delta_{\mathrm{H}} 5.94(1 \mathrm{H}, \mathrm{m}, \mathrm{H}-8)$ and $5.03-5.08(2 \mathrm{H}, \mathrm{m}, \mathrm{H}-9)$, one methoxy at $\delta_{\mathrm{H}} 3.74(3 \mathrm{H}, \mathrm{s}, \mathrm{OMe}-2)$ and one methyl at $\delta_{\mathrm{H}} 0.87\left(3 \mathrm{H}, \mathrm{t}, J=7.2 \mathrm{~Hz}, \mathrm{Me}-6^{\prime \prime \prime}\right)$. In addition, two obvious anomeric protons at $\delta_{\mathrm{H}} 4.84$ $\left(1 \mathrm{H}, \mathrm{d}, J=7.2 \mathrm{~Hz}, \mathrm{H}-1^{\prime}\right)$ and $4.09\left(1 \mathrm{H}, \mathrm{d}, J=7.8 \mathrm{~Hz}, \mathrm{H}-1^{\prime \prime}\right)$ which correlated with carbon signals at $\delta_{\mathrm{C}} 100.2\left(\mathrm{C}-1^{\prime}\right)$ and $102.8\left(\mathrm{C}-1^{\prime \prime}\right)$ observed in the HSQC spectrum, indicated two pyranose moieties. The relatively large coupling constants of anomeric protons indicated that the two pyranose moieties possessed $\beta$-linkages. The ${ }^{13} \mathrm{C}$-NMR and HSQC spectra of 2 showed twenty-eight carbon signals (Table 1), classified into two methyls (including one methoxy at $\delta_{\mathrm{C}} 55.6(\mathrm{OMe}-2)$ ), eight methylenes (including two oxygenated methylenes at $\delta_{\mathrm{C}} 60.8\left(\mathrm{C}-6^{\prime}\right)$ and $61.1\left(\mathrm{C}-6^{\prime \prime}\right)$, one terminal double bond at $\delta_{\mathrm{C}} 115.49$ (C-9), and six high field methylenes), fourteen methines (including one olefinic carbon at $\delta_{\mathrm{C}} 137.9(\mathrm{C}-8)$, three phenyl carbons at $\delta_{\mathrm{C}} 112.9$ (C-3), 120.8 (C-5), 115.53 (C-6), eight oxygenated methines, and two anomeric carbons at $\delta_{\mathrm{C}} 100.2\left(\mathrm{C}-1^{\prime}\right)$ and $\left.102.8\left(\mathrm{C}-1^{\prime \prime}\right)\right)$, and four quaternary carbons (including three phenyl carbons at $\delta_{\mathrm{C}} 144.86$ (C-1), 144.87 (C-2) and 133.4 (C-4)), with twelve to two pyranose units. The two pyranose units were identified as D-glucose by means of the same method described above. Analysis of the ${ }^{1} \mathrm{H}$ and ${ }^{13} \mathrm{C}-\mathrm{NMR}$ data of 2 revealed a strong similarity to that of 2,6-dimethoxy-4-(prop-2-enyl) phenyl $O$ - $\alpha$-L-rhamnopyranosyl-(1 $\rightarrow 6$ )- $\beta$-D-glucopyranoside [14], except for the differences in the phenyl and sugar chain moieties. Preliminary inspection of the NMR data of the phenyl moiety revealed the presence of only one methyl at $C-2$, instead of two methyls at $C-2$ and C-6 in 2,6-dimethoxy-4-(prop-2-enyl) phenyl $O-\alpha$-L-rhamnopyranosyl-( $1 \rightarrow 6)-\beta$-D-glucopyranoside as established by the typical $\mathrm{ABX}$ system of 2 and the significant long range correlations of $\mathrm{H}-3 / \mathrm{C}-1$, C-2, C-4, C-5, and C-7; H-5/C-1, C-3, and C-7; H-6/C-1, C-2, and C-4 in the HMBC spectrum (Figure 2). Detailed analysis of the sugar chain of $\mathbf{2}$ indicated that two $\beta$-D-glucoses in $\mathbf{2}$ linked through a different C-4' $4^{\prime}$ C- $4^{\prime \prime}$ linking mode, which was consolidated by the HMBC correlations of $\mathrm{H}-4^{\prime \prime} / \mathrm{C}-4^{\prime}, \mathrm{C}-2^{\prime \prime}$, and $\mathrm{C}-5^{\prime \prime}, \mathrm{H}-2^{\prime \prime}$ and $\mathrm{H}-5^{\prime \prime} / \mathrm{C}-4^{\prime \prime}$. With respect to the linking mode of the sugar chain, one additional (1-ethylcyclopropyl) methanol group was assigned at C-1" of the outer $\beta$-D-glucose, which were confirmed by the HMBC correlations of $\mathrm{H}-1^{\prime \prime \prime} \mathrm{a} / \mathrm{C}-1^{\prime \prime}, \mathrm{C}-3^{\prime \prime \prime}$, and $\mathrm{C}-4^{\prime \prime \prime}, \mathrm{H}-1^{\prime \prime \prime} \mathrm{b} / \mathrm{C}-1^{\prime \prime}, \mathrm{C}-3^{\prime \prime \prime}$, and $\mathrm{C}-4^{\prime \prime \prime}$, $\mathrm{H}-4^{\prime \prime \prime} \mathrm{a} / \mathrm{C}-1^{\prime \prime \prime}, \mathrm{C}-2^{\prime \prime \prime}$, and C-3"', $\mathrm{H}-6^{\prime \prime \prime} / \mathrm{C}-2^{\prime \prime \prime}$ and $\mathrm{C}-5^{\prime \prime \prime}$. The substitution site of the sugar chain at $\mathrm{C}-1$ was thus unequivocally established by key HMBC correlation peaks from $\mathrm{H}-1^{\prime}{ }_{\text {glc }}$ to $\mathrm{C}-1\left(\delta_{\mathrm{C}} 144.86\right)$ (Figure 2). Finally, compound 2 was identified as 2-methoxy-4-(prop-2-enyl)-1"-(1-ethylcyclopropyl) methanol phenyl $O-\beta$-D-glucopyranosyl-( $4 \rightarrow 4)$ - $\beta$-D-glucopyranoside.

Compound 3 was obtained as a brown gum. The molecular formula of $\mathrm{C}_{17} \mathrm{H}_{18} \mathrm{O}_{8}$ was established by its ${ }^{13} \mathrm{C}-\mathrm{NMR}$ and $(+)$ HRESIMS spectrum, which provided an ion peak at $\mathrm{m} / \mathrm{z} 373.0953[\mathrm{M}+\mathrm{Na}]^{+}$ (calcd for $\mathrm{C}_{17} \mathrm{H}_{18} \mathrm{NaO}_{8}, 373.0894$ ), representing nine degrees of unsaturation. With the aid of ${ }^{13} \mathrm{C}-\mathrm{NMR}$ and HSQC spectra, the seventeen carbons (Table 1) were classified into one methoxy at $\delta_{\mathrm{C}} 52.3(\mathrm{OMe}-7)$, one methylene, nine methines (including three aromatic carbons at $\delta_{\mathrm{C}} 115.3\left(\mathrm{C}-2^{\prime}\right), 116.2\left(\mathrm{C}-5^{\prime}\right)$ and 121.9 $\left(\mathrm{C}-6^{\prime}\right)$, three olefinic methines at $\delta_{\mathrm{C}} 140.1(\mathrm{C}-6), 145.9\left(\mathrm{C}-7^{\prime}\right)$, and $114.4\left(\mathrm{C}-8^{\prime}\right)$, and three oxygenated methines at $\delta_{\mathrm{C}} 70.2(\mathrm{C}-1), 68.0(\mathrm{C}-2)$, and $\left.65.8(\mathrm{C}-5)\right)$, six quaternary carbons (including two ester carbonyls at $\delta_{\mathrm{C}} 166.7(\mathrm{C}-7)$ and $166.5\left(\mathrm{C}-9^{\prime}\right)$, three aromatic carbons at $\delta_{\mathrm{C}} 125.9\left(\mathrm{C}-1^{\prime}\right), 146.0\left(\mathrm{C}-3^{\prime}\right)$, and $148.9\left(\mathrm{C}-4^{\prime}\right)$, and one olefinic carbon at $\left.\delta_{\mathrm{C}} 140.1(\mathrm{C}-6)\right)$. The proton and carbon NMR data of 3 were very similar to those of 1-(3', $4^{\prime}$-dihydroxylcinnamoyl)-cyclopenta-2,5-diol [15], with the exception of one additional methyl acetate group connected with $\mathrm{C}-3$ via $\mathrm{C}_{3}=\mathrm{C}_{6}$ double bond, which was further proved by a combined interpretation of HMBC correlations of H-1 $\left(\delta_{\mathrm{H}} 5.10\right) / \mathrm{C}-2, \mathrm{C}-3, \mathrm{C}-4, \mathrm{C}-5, \mathrm{C}-9^{\prime}, \mathrm{H}-2$ $\left(\delta_{\mathrm{H}} 3.78\right) / \mathrm{C}-1, \mathrm{C}-2, \mathrm{C}-3, \mathrm{C}-6, \mathrm{H}_{2}-4\left(\delta_{\mathrm{H}} 2.65-2.69,2.21-2.25\right) / \mathrm{C}-1, \mathrm{C}-2, \mathrm{C}-4, \mathrm{C}-5, \mathrm{C}-6, \mathrm{H}-5\left(\delta_{\mathrm{H}} 4.28\right) / \mathrm{C}-1$, C-3, C-4, C-5, H-6 ( $\left.\delta_{\mathrm{H}} 6.72\right)$ with C-2, C-3, C-4, C-7, OMe $\left(\delta_{\mathrm{H}} 3.69\right) / \mathrm{C}-7$ (Figure 2).

The relative configuration of 3 was determined as shown in Figure 2 by comprehensive analysis of the NOESY correlations and coupling constants. The NOE correlations of $\mathrm{H}-1 / \mathrm{H}-2, \mathrm{H}-4 \mathrm{a}$, H-4b; H-2/H-1, H-4b, H-5; H-5/H-4a, H-6 (Figure 2b), banded with the small coupling constants of $\mathrm{H}-1$ with $\mathrm{H}-2(J=6.6 \mathrm{~Hz})$ and $\mathrm{H}-1$ with $\mathrm{H}-5(J=4.8 \mathrm{~Hz})$, demonstrated the $\beta$-orientations 
for $\mathrm{H}-1, \mathrm{H}-2$ and H-5, and $\alpha$-orientations for $\mathrm{OH}-2$ and $\mathrm{OH}-5$. In addition, the $\mathrm{Z}$ form of the olefinic geometries of C-3/C-6 was deduced by the NOE correlation of H-6/H-5. The absolute configuration of 3 was determined by comparing its experimental ECD spectrum with that of $(3 S, 5 R, 6 S, 7 E) 3,5,6$-trihydroxy-7-megastigmen-9-one [16,17], where the curve trend of 3 displayed a negative cotton effect at $222 \mathrm{~nm}$ consistent with the $2 S$ enantiomer. Consequently, compound 3 was assigned $1 S, 2 S$, and $5 S$ configurations based on the above mentioned NOESY correlations, and the structure was elucidated as $(Z)-(1 S, 2 S, 5 S)-2,5$-dihydroxy-3-(2-methoxy-2-oxoethylidene)cyclopentyl 3-(3,4-dihydroxyphenyl) acrylate.
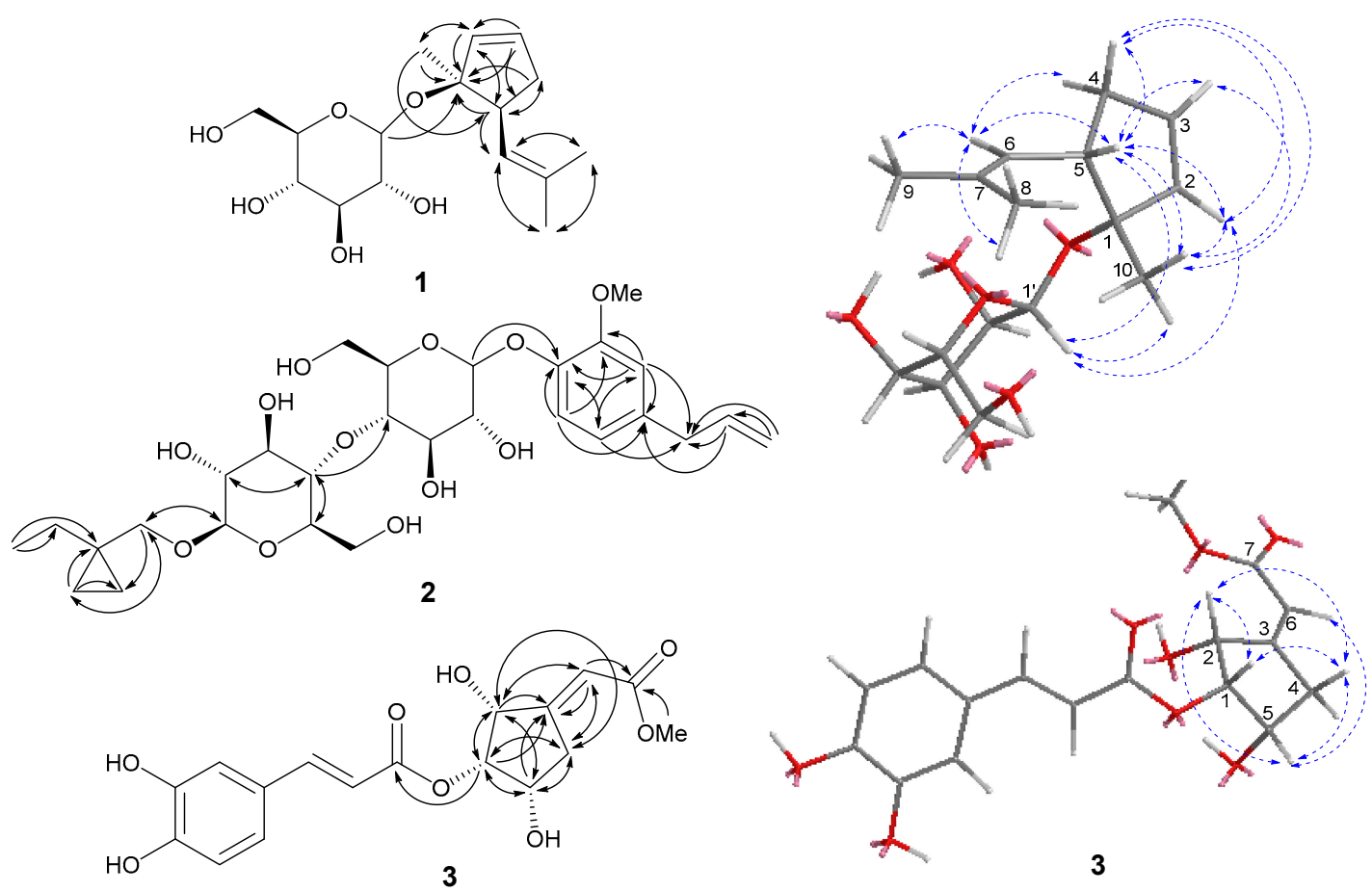

Figure 2. Key heteronuclear multiple-bond correlation $(\mathrm{HMBC})(\mathrm{H} \longrightarrow \mathrm{C})$ correlations of 1-3 (left), and key NOESY $(\mathrm{H} \triangleleft \cdots \cdots \cdot \mathrm{H})$ correlations of $\mathbf{1}$ and $\mathbf{3}$ (right).

The anti-inflammatory activities of compounds 1-7 were evaluated against nitric oxide (NO) production in an in vitro inflammatory model of macrophage Raw 264.7 cells because the application of $S$. officinalis as a folk medicinal plant concerns the treatment of inflammation. The results of the bioassay were shown in Table 2 and Figure 3, which showed that compounds 3 and 7 exhibited moderate inhibitory effects on $\mathrm{NO}$ production with $\mathrm{IC}_{50}$ values of $12.2 \pm 0.8$ and $18.9 \pm 0.3 \mu \mathrm{M}$, respectively. However, the anti-inflammatory activities of compounds 1, 2, 4, 5, and 6 against nitric oxide production were weaker compared with the positive control dexamethasone $(2.2 \pm 0.02 \mu \mathrm{M})$. Other compounds were inactive $\left(\mathrm{IC}_{50}>100 \mu \mathrm{M}\right)$. In addition, the cytotoxicity against macrophage Raw 264.7 cells of compounds 1-7 were also investigated using the MTT method, and none showed any cell toxicity at a concentration of $20 \mu \mathrm{M}$ (Table 2). In conclusion, we can state that $S$. officinalis is an interesting source of active compounds. The hydroxyl substituted benzene ring and conjugated ester moiety might take significant effect for anti-inflammatory activity. 
Table 2. Inhibitory effects on NO production against Raw 264.7 cells of compounds 1-7 and their cytotoxicities ${ }^{\text {a }}$.

\begin{tabular}{ccc}
\hline \multirow{2}{*}{ Compounds } & IC $_{\mathbf{5 0}}(\boldsymbol{\mu M})$ & Inhibition Rate $(\%)^{\mathbf{b}}$ \\
\cline { 2 - 3 } & NO & Cytotoxicity \\
\hline $\mathbf{1}$ & $>100$ & 1.8 \\
$\mathbf{2}$ & $>100$ & -0.5 \\
$\mathbf{3}$ & $12.2 \pm 0.8$ & 4.7 \\
$\mathbf{4}$ & $>100$ & 1.1 \\
$\mathbf{5}$ & $>100$ & 4.5 \\
$\mathbf{6}$ & $>100$ & 1.2 \\
$\mathbf{7}$ & $18.9 \pm 0.3$ & 2.4 \\
Dexamethasone & $2.2 \pm 0.02$ & $\mathrm{NT}^{\mathrm{c}}$ \\
\hline
\end{tabular}

${ }^{\text {a }}$ All results are expressed as mean $\pm \mathrm{SD} ; n=3$ for all groups. ${ }^{\mathrm{b}}$ Test at a concentration of $20 \mu \mathrm{M} .{ }^{\mathrm{c}}$ Not tested.
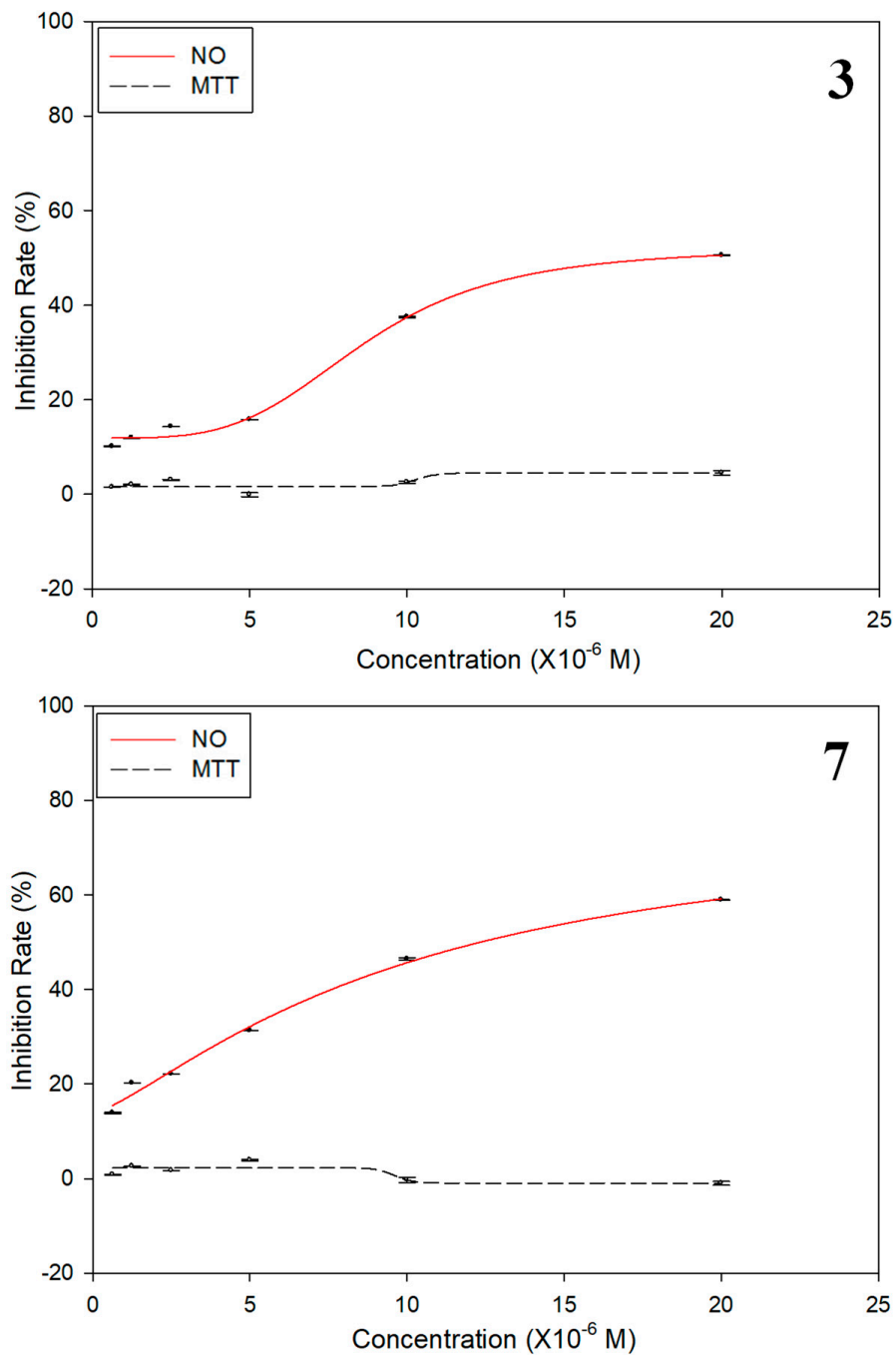

Figure 3. $\mathrm{IC}_{50}$ values of compounds 3 and 7 on NO production in LPS-induced Raw 264.7 cells. (Raw 264.7 cells were subjected to compounds 3 and 7 with six different concentrations and incubated for $2 \mathrm{~h}$ firstly, and then stimulated by adding LPS for $24 \mathrm{~h}$. Then, Griess reagents I and II were added to cell supernatants to detect the NO production levels. The cytotoxicity against macrophage Raw 264.7 cells of compounds 3 and 7 were investigated using the MTT method; NO: Inhibition rates of NO release (\%); MTT: Inhibition rates of cell viability (\%)). 


\section{Materials and Methods}

\subsection{General}

Optical rotations were determined using a SEEWE SGW-2 digital polarimeter. ECD data were recorded on an Applied Photophysics Chirascan ECD spectrometer. An HRESI-MS analysis was obtained using a Bruker Impact II mass spectrometer. The 1D and 2D NMR spectra were taken on either a BURKER 400 NMR or a Varian 600 NMR spectrometer. The preparative HPLC experiments were conducted on a Shimadzu LC-6AD packed with an SPD-10A detector and a reversed-phase $\mathrm{C}_{18}$ column (Shim-pack PREP-ODS (H). Kit, $20 \times 250 \mathrm{~mm}, 5 \mu \mathrm{m}$ ). Silica gel (200-300 mesh, Qingdao Haiyang Chemical Co. Ltd., Qingdao, China), and ODS (45 $\mu \mathrm{m}$, YMC Co. Ltd., Kyoto, Japan) were used for column chromatography (CC). HPLC grade Acetonitrile (MeCN) was used for preparative HPLC experiments, and other solvents were of analytical grade.

\subsection{Plant Material}

The origin of S. officinalis was identical to that mentioned in our previous studies [8,9].

\subsection{Extraction and Isolation}

Air-dried and pulverized stems of S. officinalis $(10 \mathrm{Kg})$ were extracted with $95 \% \mathrm{EtOH}$ three times $(2 \mathrm{~h}, 1 \mathrm{~h}, 1 \mathrm{~h})$ under reflux conditions, and the condensed extracts were successively subjected to multi-solvent partition with petroleum ether, EtOAc, and $n$ - $\mathrm{BuOH}$ sequentially as previously described [6]. The EtOAc fraction was subjected to $\mathrm{CC}$ over silica gel fractionation to furnish eleven fractions (designated as fractions 1 to 11). Fraction 4 ( $3.0 \mathrm{~g}$, eluted with $\mathrm{CH}_{2} \mathrm{Cl}_{2} / \mathrm{MeOH}$, 15:1) was fractioned by a Flash $\mathrm{C}_{18}$ column eluted with gradient elution of $\mathrm{MeOH} / \mathrm{H}_{2} \mathrm{O}(5 \% \rightarrow 100 \%)$ to yield five subfractions (F4-1-F4-5). Fraction 4-3 (2.5 g, eluted with $12 \% \mathrm{MeOH} / \mathrm{H}_{2} \mathrm{O}$ ) was further chromatographed on a Flash $\mathrm{C}_{18}$ column by gradient elution of $\mathrm{MeOH} / \mathrm{H}_{2} \mathrm{O}(5 \% \rightarrow 100 \%)$ to give compound $4(22 \mathrm{mg}, \mathrm{tR}=5.689 \mathrm{~min}$, purity of $97 \%$ by HPLC analysis $)$ and compound $5(17 \mathrm{mg}$, $\mathrm{tR}=10.000$ min, purity of $96 \%$ by HPLC analysis). Fraction 5 (10.6 g, eluted with $\mathrm{CH}_{2} \mathrm{Cl}_{2} / \mathrm{MeOH}$, 15:1) was separated on a Flash $\mathrm{C}_{18}$ column with gradient elution of $\mathrm{MeOH} / \mathrm{H}_{2} \mathrm{O}(12 \% \rightarrow 100 \%)$ to give four subfractions (F5-1-F5-4). Fraction 5-2 (2.1 g, eluted with $45 \% \mathrm{MeOH} / \mathrm{H}_{2} \mathrm{O}$ ) was further chromatographed to give ten subfractions (F5-2-1-F5-2-10), using a Flash $\mathrm{C}_{18}$ column by gradient elution of $\mathrm{MeOH} / \mathrm{H}_{2} \mathrm{O}(5 \% \rightarrow 100 \%)$. Fraction 5-2-5 (60 mg, eluted with $\left.45 \% \mathrm{MeOH} / \mathrm{H}_{2} \mathrm{O}\right)$ was further purified using preparative HPLC (mobile phase: $\mathrm{MeCN} / \mathrm{H}_{2} \mathrm{O}(20: 80, v / v)$; flow rate: $3 \mathrm{~mL} \mathrm{~min}{ }^{-1}$; UV detection at $210 \mathrm{~nm})$ to obtain compound $2(4 \mathrm{mg}, \mathrm{tR}=20.600 \mathrm{~min}$, purity of $91 \%$ by HPLC analysis $)$ and compound $6(10 \mathrm{mg}$, tR $=14.248 \mathrm{~min}$, purity of $92 \%$ by HPLC analysis), respectively. Fraction 5-3 (1.2 g, eluted with $60 \% \mathrm{MeOH} / \mathrm{H}_{2} \mathrm{O}$ ) was further fractioned to give ten subfractions (F5-3-1-F5-3-10) by a Flash $\mathrm{C}_{18}$ column eluted with $\mathrm{MeOH} / \mathrm{H}_{2} \mathrm{O}(5 \% \rightarrow 100 \%)$. Compound $\mathbf{1}(12 \mathrm{mg}, \mathrm{tR}=12.970 \mathrm{~min}$, purity of $93 \%$ by HPLC analysis) was purified using preparative HPLC system [mobile phase: $\mathrm{MeCN} / \mathrm{H}_{2} \mathrm{O}$ $(30: 70, v / v)$; flow rate: $3 \mathrm{~mL} \mathrm{~min}^{-1}$; UV detection at $210 \mathrm{~nm}$ ] from Fraction 5-3-9 $(60 \mathrm{mg}$, eluted with $60 \%$ $\mathrm{MeOH} / \mathrm{H}_{2} \mathrm{O}$ ). Fraction 6 (5.0 g, eluted with $\mathrm{CH}_{2} \mathrm{Cl}_{2} / \mathrm{MeOH}$, 15:1) was chromatographed on a Flash $\mathrm{C}_{18}$ column with a $\mathrm{MeOH} / \mathrm{H}_{2} \mathrm{O}$ gradient $(5 \% \rightarrow 100 \%)$ to give nine subfractions (F6-1-F6-9). Compound 7 ( $26 \mathrm{mg}$, tR $=10.189 \mathrm{~min}$, purity of $95 \%$ by HPLC analysis) was purified using preparative HPLC

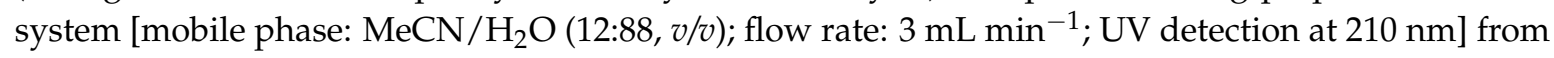
fraction 6-1 (100 mg, eluted with 5\% $\mathrm{MeOH} / \mathrm{H}_{2} \mathrm{O}$ ). Fraction 7 (5.0 g, eluted with $\left.\mathrm{CH}_{2} \mathrm{Cl}_{2} / \mathrm{MeOH}, 10: 1\right)$ was separated using Flash $\mathrm{C}_{18} \mathrm{CC}$ with a $\mathrm{MeOH} / \mathrm{H}_{2} \mathrm{O}$ gradient $(5 \% \rightarrow 100 \%)$ to give six subfractions (F7-1-F7-6). Fraction 7-1 (0.8 g, eluted with $12 \% \mathrm{MeOH} / \mathrm{H}_{2} \mathrm{O}$ ) was further chromatographed by CC over Sephadex LH-20 with $\mathrm{MeOH}$ as mobile phase to give five subfractions (F7-1-1-F7-1-5). Compound 3 (12 $\mathrm{mg}, \mathrm{tR}=25.476 \mathrm{~min}$, purity of $91 \%$ by HPLC analysis) was purified using preparative HPLC system

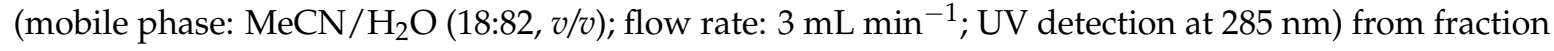
7-1-5 (80 mg). 
(rel)-(1R, 5R)-1-Methyl-5-(2-methylprop-1-en-1-yl)cyclopent-2-en-1-O- $\beta$-D-glucopyranoside (1): brown, gum; $[\alpha]_{\mathrm{D}}^{20}-25.0(c 0.067, \mathrm{MeOH}) .{ }^{1} \mathrm{H}$ (DMSO- $d_{6}, 400 \mathrm{MHz}$ ) and ${ }^{13} \mathrm{C}-\mathrm{NMR}$ (DMSO- $d_{6}, 100 \mathrm{MHz}$ ), see Table 1 ; HRESIMS (positive-ion mode): $m / z 337.1802[\mathrm{M}+\mathrm{Na}]^{+}$(calcd for $\mathrm{C}_{16} \mathrm{H}_{26} \mathrm{NaO}_{6}, 337.1622$ ).

2-Methoxy-4-(prop-2-enyl)-1"-(1-ethylcyclopropyl) methanol phenyl $O$ - $\beta$-D-glucopyranosyl-(4 $\rightarrow 4)-\beta$-D -glucopyranoside (2): light yellow, amorphous powder; $[\alpha]_{\mathrm{D}}^{20}-23.7$ (c 0.09, MeOH). ${ }^{1} \mathrm{H}$ (DMSO- $d_{6}$, $600 \mathrm{MHz}$ ) and ${ }^{13} \mathrm{C}-\mathrm{NMR}$ (DMSO- $d_{6}, 150 \mathrm{MHz}$ ), see Table 1; HRESIMS (positive-ion mode): $\mathrm{m} / \mathrm{z}$ $571.2798[\mathrm{M}+\mathrm{H}]^{+}$(calcd for $\left.\mathrm{C}_{28} \mathrm{H}_{43} \mathrm{O}_{12}, 571.2749\right)$.

(Z)-(1S,2S,5S)-2,5-Dihydroxy-3-(2-methoxy-2-oxoethylidene)cyclopentyl 3-(3,4-dihydroxyphenyl) acrylate (3): brown, gum; $[\alpha]_{\mathrm{D}}^{20}-34.1($ c $0.27, \mathrm{MeOH}) .{ }^{1} \mathrm{H}\left(\mathrm{DMSO}-d_{6}, 600 \mathrm{MHz}\right)$ and ${ }^{13} \mathrm{C}-\mathrm{NMR}$ (DMSO- $\left.d_{6}, 150 \mathrm{MHz}\right)$, see Table 1; HRESIMS (positive-ion mode): $m / z 373.1013[\mathrm{M}+\mathrm{Na}]^{+}$(calcd for $\mathrm{C}_{17} \mathrm{H}_{18} \mathrm{NaO}_{8}, 373.0894$ ).

\subsection{Acid Hydrolysis of Compounds $\mathbf{1}$ and $\mathbf{2}$ to Determine the Absolute Configuration of the Monosaccharides}

Compounds $\mathbf{1}$ and $\mathbf{2}$ were subjected to acid hydrolysis the same as described in our previous study [8], as well as the determination of absolute sugar moiety configurations. The hydrolyzed aqueous fraction was further detected and identified as glucose comparing with the authentic glucose sample by thin layer plate analysis, using $\mathrm{CHCl}_{3}-\mathrm{CH}_{3} \mathrm{OH}-\mathrm{H}_{2} \mathrm{O}$ (15:9:2) as a developing solvent and $10 \% \mathrm{H}_{2} \mathrm{SO}_{4}$ in $95 \% \mathrm{EtOH}$ as a detection reagent. Then, the methylated thiazolidine derivatives of the hydrolyzed sugar moieties and the corresponding authentic glucose were prepared, and their absolute configurations were further identified by comparing the retention times of the hydrolyzed sugar derivatives with that of the authentic glucose derivative in the GC analysis (conditions in the experiment were as follows: DB- 5 column, $30 \mathrm{~m} \times 250 \mu \mathrm{m} \times 0.25 \mu \mathrm{m}$; FID detection; carrier gas of $\mathrm{N}_{2}$; injection temperature of $250{ }^{\circ} \mathrm{C}$, detection temperature of $260^{\circ} \mathrm{C}$, column temperature of $60^{\circ} \mathrm{C}(0 \mathrm{~min})$ raised up to $300^{\circ} \mathrm{C}$ in $24 \mathrm{~min}$ by $10^{\circ} \mathrm{C} / \mathrm{min}$, and $300^{\circ} \mathrm{C}$ kept for $10 \mathrm{~min}$. tR D-glucose $21.10 \mathrm{~min}$ ).

\subsection{Anti-Inflammatory Activity Assay Against NO Production}

The anti-inflammatory activity assay against NO production in RAW 264.7 mouse peritoneal macrophages was conducted mainly using the procedures described previously [18]. The macrophage Raw 264.7 cells were subjected to dexamethasone (Sigma, St. Louis, MO, USA, $>98 \%$ ) and isolated compounds (1-7) with six concentrations of $0.63,1.25,2.5,5.0,10$ and $20 \mu \mathrm{M}$ and incubated for $2 \mathrm{~h}$ firstly, and then stimulated by adding lipoplysaccharide (LPS, $1.0 \mu \mathrm{g} / \mathrm{mL}$ ). After being stimulated for $24 \mathrm{~h}, 50 \mu \mathrm{L}$ of cell supernatants were taken out from each well and mixed with an equal volume of Griess reagents I and II to detect the NO production levels by measuring absorbance at $570 \mathrm{~nm}$. All experiments were performed in triplicate. The NO inhibition is calculated as the percentage reduction of LPS stimulation.

The cytotoxicity against macrophage Raw 264.7 cells was investigated using the MTT assay [9]. Briefly, after the Raw 264.7 cells were treated with the test compounds for $24 \mathrm{~h}, 50 \mu \mathrm{L}$ of MTT ( $5 \mathrm{mg} / \mathrm{mL}$ ) was added to each well, and the cells were incubated for an additional $4 \mathrm{~h}$. After the formazan crystals formed, cell supernatants were removed and $100 \mu \mathrm{L}$ of DMSO was added to dissolve the crystals. Absorbance for each well was analyzed in the same way as that for NO inhibition assay.

\section{Conclusions}

In the present study, one new monoterpene glycoside (1), one new phenyl glycoside (2), one new caffeoyl derivative (3), and four known compounds (4-7) were isolated from S. officinalis. This is the first time that these kinds of compounds are reported in the title plant. Compounds 3 and 7 exhibited moderate inhibitory effects on NO production, and neither showed any cell toxicity against macrophage Raw 264.7 cells. Meanwhile, none of the other five compounds showed any anti-inflammatory activities. These definite pharmacological findings indicated limited structure-activity relationships as hydroxyl substituted benzene rings and conjugated ester moieties might take significant effect for 
anti-inflammatory activity, supported the application of the S. officinalis in Miao ethnomedicine system to treat inflammation.

Supplementary Materials: Supplementary data (NMR and MS spectroscopic data for compounds 1-3) associated with this article are available online.

Author Contributions: H.D. and J.Y. carried out the research work and drafted the manuscript; X.W. (Xueyong Wang) supplied the plant material; J.Y. and X.S. assisted in the isolation and structural elucidation of isolated compound; Y.G. and X.W. (Xiao Wang) advised in the activity testing. All authors discussed and approved the final version of this manuscript.

Funding: This research was funded by Shandong Provincial Natural Science Foundation, China (BS2015YY035, ZR2016YL006, ZR2018QH006), Shandong Province Major Scientific and Technological Innovation Project (Grant Nos. 2017CXGC1209, 2017CXGC1308), and The Priority Research Program of the Shandong Academy of Sciences (Lanping Guo).

Acknowledgments: We thank Xueyong Wang for the sample authentication. This work was supported by Shandong Provincial Natural Science Foundation, China (BS2015YY035, ZR2016YL006, ZR2018QH006), Shandong Province Major Scientific and Technological Innovation Project (Grant No. 2017CXGC1209, 2017CXGC1308), and The Priority Research Program of the Shandong Academy of Sciences (Lanping Guo).

Conflicts of Interest: The authors declare no conflicts of interest.

\section{References}

1. $\mathrm{Li}, \mathrm{H}$. Search the origin of Araceae by ecological geography. Acta Bot. Yunnanica 1996, 18, 14-42.

2. $\quad$ El-Desouky, S.K.; Kim, K.H.; Ryu, S.Y; Eweas, A.F.; Gamal-Eldeen, A.M.; Kim, Y.K. A new pyrrole alkaloid isolated from Arum palaestinum Boiss. and its biological activities. Arch. Pharm. Res. 2007, 30, 927-931. [CrossRef] [PubMed]

3. Huang, W.J.; Yi, X.M.; Feng, J.Y.; Wang, Y.H.; He, X.J. Piperidine alkaloids from Alocasiamacrorrhiza. Phytochemistry 2017, 143, 81-86. [CrossRef] [PubMed]

4. Clark, B.R.; Bliss, B.J.; Suzuki, J.Y.; Borris, R.P. Chemotaxonomy of Hawaiian Anthurium cultivars based on multivariate analysis of phenolic metabolites. J. Agric. Food Chem. 2014, 62, 11323-11334. [CrossRef] [PubMed]

5. Roshan, R.; Ahmed, S.; Hasan, M.M. Arisaema jacquemontii Blume (Araceae): A review of medicinal uses, phytochemistry and pharmacology. J. Pharmacogn. Phytochem. 2017, 6, 429-432.

6. Wu, Y.Y.; Huang, X.X.; Zhang, M.Y.; Zhou, L.; Li, D.Q.; Cheng, Z.Y.; Li, L.Z.; Peng, Y.; Song, S.J. Chemical constituents from the tubers of Pinellia ternate (Araceae) and their chemotaxonomic interest. Biochem. Syst. Ecol. 2015, 62, 236-240. [CrossRef]

7. Li, D.D.; Fang, M.L.; Liu, Q.; Li, Q.L.; Gao, Y.T. Study on the extraction of polyphenol from Scindapsus officinalis with ultrasonic wave technology optimized by central composite design-response surface method. J. Chin. Mater. Med. 2011, 34, 129-133.

8. Yu, J.Q.; Song, X.Y.; Wang, D.J.; Wang, X.Y.; Wang, X. Five new chromone glycosides from Scindapsus officinalis (Roxb.) Schott. Fitoterapia 2017, 122, 101-106. [CrossRef] [PubMed]

9. Yu, J.Q.; Song, X.Y.; Yang, P.; Wang, X.Y.; Wang, X. Alkaloids from Scindapsus officinalis (Roxb.) Schott. and their biological activities. Fitoterapia 2018, 129, 54-61. [CrossRef] [PubMed]

10. Dong, L.M.; Jia, X.C.; Luo, Q.W.; Zhang, Q.; Luo, B.; Liu, W.B.; Zhang, X.; Xu, Q.L.; Tan, J.W. Phenolics fromMikaniamicrantha and their antioxidant activity. Molecules 2017, 22, 1140. [CrossRef] [PubMed]

11. Kurashima, K.; Fujii, M.; Ida, Y.; Akita, H. Simple synthesis of $\beta$-D-Glycopyranosides using $\beta$-Glycosidase from almonds. Chem. Pharm. Bull. 2004, 52, 270-275. [CrossRef] [PubMed]

12. Zhang, H.C.; Wang, Y.; Yu, C.M.; Yu, D.H.; Chen, P.P.; Liu, S.M. Two new saccharide fatty acid esters from the fruit of Morindacitrifolia L. and their ABTS radical scavenging activities. Rec. Nat. Prod. 2014, 8, 25-31.

13. Marzouk, M.S.; Moharram, F.A.; El Dib, R.A.; El-Shenawy, S.M.; Tawfike, A.F. Polyphenolic profile and bioactivity study of Oenotheraspeciosa Nutt. aerial parts. Molecules 2009, 14, 1456-1467. [CrossRef] [PubMed]

14. Bai, H.Y.; Hu, L.H. Study on the chemical constituents of Daphniphyllum angustifolium. Helv. Chim. Acta 2006, 89, 884-894. [CrossRef]

15. Wang, H.B.; Nair, M.G.; Strasbur, G.M.; Booren, A.M.; Gray, J.I. Novel antioxidant compounds from Tart Cherries (Prunuscerasus). J. Nat. Prod. 1999, 62, 86-88. [CrossRef] [PubMed] 
16. Mori, K. Syntheses of optically active grasshopper ketone and dehydrovomifoliol as a synthetic support for the revised absolute configuration of (+)-abscisic acid. Tetrahedron 1974, 30, 1065-1072. [CrossRef]

17. Della, G.M.; Marino, C.D.; Zarrelli, A. Isolation and phytotoxicity of apocarotenoids from Chenopodium album. J. Nat. Prod. 2004, 67, 1492-1495.

18. Chae, H.S.; Yoo, H.; Kim, Y.M.; Choi, Y.H.; Lee, C.H.; Chin, Y.W. Anti-Inflammatory Effects of 6,8-Diprenyl-7,4'-dihydroxyflavanone from Sophoratonkinensis on Lipopolysaccharide-Stimulated RAW 264.7 Cells. Molecules 2016, 21, 1049. [CrossRef] [PubMed]

Sample Availability: Samples of the compounds (1-3) are available from the authors.

(C) 2018 by the authors. Licensee MDPI, Basel, Switzerland. This article is an open access article distributed under the terms and conditions of the Creative Commons Attribution (CC BY) license (http:/ / creativecommons.org/licenses/by/4.0/). 